\title{
EXPLORING EFL STUDENTS' PROBLEMS IN LISTENING TO ENGLISH NEWS BROADCASTS
}

\author{
Zulfikarr $^{1}$, Cut Tarri Aulia' ${ }^{2}$, Saiful Akmal ${ }^{3}$ \\ ${ }^{1}$ Sekolah Tinggi Agama Islam Negeri Mandailig Natal, Mandailing Natal, Indonesia \\ 2, 3Universitas Islam Negeri Ar-Raniry, Banda Aceh, Indonesia \\ E-mail: zulfikar@stain-madina.ac.id
}

Received: 21 September 2020

Accepted: 06 December 2020

\begin{abstract}
Listening is central for language learning and for daily communication. However, in foreign language learning, students still encounter problems in understanding listening materials. This present study is aimed to reveal the students' problems in listening English news broadcasts. The subjects of this study were two classrooms at the Department of English Language Education at an acknowledged university in Banda Aceh. The samples were made of 50 students in their third semester. This study employed a quantitative analysis approach. A close-ended questionnaire was used as the instruments in collecting the data. The findings showed that the difficulties faced by the students in listening to English news broadcast were mainly caused by unfamiliar topics, unfamiliar vocabulary, different accents, fast speech rate, unintelligible pronunciation, difficulty in inference making, excessively long passages, complicated grammatical structure, as well as complex ideas.
\end{abstract}

Keywords: language learning, foreign language, listening materials, English news broadcasts.

\section{Introduction}

Listening has long been considered as one of the most imperative abilities for language learning since it is the most commonly used language skill in everyday life. The fact that listening plays a starring role in communication is well-reflected by the total time spent on communicating, in which "listening takes up 40-50\%, speaking $25-30 \%$, reading $11-16 \%$, and writing about 9\%" (Mendelsohn, as cited in Gilakjani \& Ahmadi, 2011). Nevertheless, listening is also commonly considered as one of the most challenging skills to learn for EFL learners since extra attention and concentration are needed to comprehend speakers' utterances. Listening, as a process of converting spoken language to meaning in the mind, is a multifaceted process in which many things take place concurrently in one's brain.

One noticeable obstacle in listening comprehension is the pronunciation of the words which may depart significantly from how they are written (Bloomfield et al., 2010). Vocabulary may also pose another problem to EFL learners. In fact, the overlap between a learner's vocabulary and the vocabulary of a given utterance constitutes a key factor affecting his or her listening comprehension. According to Buck (2001), spoken language difficulty level tends to escalate as its vocabulary and grammar become far more idiomatic and less formal. Thus, when the vocabulary of the text is beyond learners' current vocabulary knowledge, they will most likely experience difficulties. Furthermore, the rate of speech is also an obstacle for EFL learners, especially those at a beginner level. Since 
listeners are not able to control how fast a speaker talks, EFL learners' listening comprehension may suffer when they have to process an utterance at a high rate of speech (Saraswaty, 2018).

Teachers also play a significant role in improving learners' listening skill. Usó-Juan \& Martínez-Flor (2006) reiterates that listening is such a difficult skill to explain. To cope with this difficulty, learners have to develop their listening skills and prepare themselves to be real listeners who can deal with real listening situations. Hence, teachers must provide authentic materials or real-life activities that can facilitate learners to learn the language (Akmal, 2013). Lingzhu and Yuanyuan (2010) emphasizes that using authentic materials can help learners to acquire natural language or real speech from native speakers in real life settings. There is a large variety of authentic materials to choose from for a listening class, such as interviews, dialogues, lectures, discussions, conversations or broadcasts. These materials can be easily obtained from TOEFL or IELTS books, or adopted from circulated materials such as radio programs, TV shows, and news in the media.

One of the widely available yet still rarely used learning resources in listening classroom is English news broadcast. According to Morrison (1989), English news broadcasts can function as a good learning resource for several reasons. First, they offer authentic materials intended for native speakers, but often with international topics a teacher can select and adapt to meet EFL learners' needs. Second, teachers can choose from a large variety of interesting and inspiring materials. Third, they allow learners to discuss up-to-date topics relevant to prevailing issues in their time. Fourth, they offer highly adjustable materials that teachers can exploit for many different listening activities.

This present study examines the problems faced by EFL learners in listening to English news broadcasts. It is hoped that the findings of this study can provide useful insights for English teachers in listening comprehension material development in teaching listening comprehension to EFL learners.

\section{Literature Review}

Rost (2011) describes listening as a multifaceted interpretation mechanism during which listeners align their pre-existing knowledge with the input they perceive. An adept listener is able to skillfully perform a complex process of listening which includes identifying and comprehending the sounds, the structure, the diction, and the meaning of an utterance all at once (Thomlison, as cited in Hamouda, 2013). Willis (1981) formulates a string of listening micro-skills named enabling skills, which include anticipating what the speaker will say, predicting the meaning of unfamiliar vocabulary, utilizing background knowledge, dismissing unnecessary materials, identifying lexical devices and discourse markers, comprehending prosodic features, and recognizing what is implied. Burns and Broman (1975), on the other hand, categorize listening into three types: appreciative, critical, and discriminative. On the other hand, Allen (1976) classifies listening into eight types, namely simple listening, discriminative listening, listening for information, listening for organized ideas, listening for main points, listening for varied points of view, critical listening, and creative listening.

Gilakjani and Sabouri (2016) points out some factors that may cause difficulties in listening process. They include listeners' lack of control of speakers' rate of speech, length of the passage, listeners' failure to recognize words or phrases in the passage, listener's insufficient contextual knowledge, and pronunciation of words that is quite different from what listeners might expect from the spelling. Hasan (2000) asserts that among the main problems in listening comprehension are unknown vocabulary, demanding grammar, 
lengthy and unstimulating listening passage, as well as unfamiliar accents. Furthermore, Ur (2012) maintains that among the barriers to effective listening class are common misconception among learners that they need to recognize each word uttered by the speaker, the frequent stop listeners make to figure out the meaning of unfamiliar vocabulary they encounter, and their inability to discern a passage at a high speech rate.

Additionally, Teng's 2002 study (as cited in Gilakjani \& Sabouri, 2016), reports that difficulties in listening comprehension are commonly triggered by at least four variables, which include listener variable, speaker variable, stimulus variable, and background variable. Similarly, Brown and Yule (2013) argues that listening is a challenging task not only owing to its already complicated nature, but also because of the characteristics of the audience, the speaker, the information and its visual aid.

Nowadays, mass media provides a myriad of diverse resources to EFL teachers to conveniently use throughout a listening course. The most readily available and widely used are the news broadcasts even though others are certainly as beneficial. According to Yamane and Yamane (2012), a news broadcast normally consists of a brief introduction of a story by the presenter and an elaboration involving, among others, interviews and people's opinions or experiences. Information in news broadcast is delivered dominantly in simple present tense and present progressive tense, with a frequent use of loose sentences and contractions. In narrating news, the anchors customarily recite prepared scripts, and the speed rate is relatively fast.

Using news broadcasts as a learning resource in EFL listening classroom offers a myriad of advantages. News broadcasts come in varied informative and actual themes (but still not excessively amusing), presented in a relatively short duration, thus allowing learners to retain their focus. Listening to news broadcasts prepare learners to listen to resources from multiple fields, with multiple tongues. In addition, exposing learners with news broadcasts means familiarizing them with some standardized tests they may have to take in the future such as TOEFL, IELTS, or EAP, whose materials are usually adapted from authentic sources (Liza et al., 2013).

Widdowson (2003) defined authentic materials as real-life learning source originally created and intended for the use by native speakers, such as newspaper articles, brochures, leaflets, songs, movie clips, and news broadcasts. To this date, podcast was also considered one of the most used alternative authentic materials by to improve students' listening skills (Yoestara \& Putri, 2019). They allow learners to recount the circumstances in their own life and to recognize the application of a given language construction (Wong, et al., 1995). With proper selection and application, authentic resources can be developed into classroom activities that link learners' linguistic competence and their professional objectives (Rao, 2019). As a result, learners find authentic materials more stimulating and interesting than non-authentic materials.

\section{Research Method}

The populations of this research were students of English Language Education Department at an acknowledged university in Banda Aceh. The third-semester (second-year) students were chosen for this study as the sample by using purposive sampling (Creswell \& Poth, 2013). Palinkas et al. (2015) argue that purposive sampling can also be used in quantitative and mixed method research implementation, although the nature of this sampling technique is mostly used in probability approach in qualitative research. These 50 EFL learners were recruited from 201 students of English Language Education Department 
since they had completed Listening 1 and Listening 2 and are currently participating in Listening 3 ( $25 \%$ of total population).

In collecting the data, this study used a questionnaire as the instrument (Dörnyei \& Taguchi, 2010) since the number of the participants is relatively large. Before being distributed to the participants, the questionnaire's format, organization, clarity, and word choice had been evaluated by a panel of four teachers who have had years of experience providing listening instruction in the university where the current study was carried out. The questionnaire was later revised by taking the experts' views. The revision included item modification, addition, and deletion.

The questionnaire, consisting of 23 close-ended items, was distributed to the learners after they have completed three listening comprehension sessions using English news broadcasts as materials. The survey asked for the learners' feedback on the following: overall satisfaction with their listening course; overall satisfaction with the listening comprehension materials; overall experience and satisfaction with English news broadcasts as listening materials; difficulties and strategies in listening to English news broadcasts. After obtaining the data, the results were subsequently calculated by employing Walizer \& Wienir's (1978) statistical formula:

$$
P=\frac{f}{N} \times 100 \%
$$

where:

$\mathbf{P}=$ the percentage of the responses that belong in a given category

$f=$ the frequency; the number of responses that fall into the category

$\mathbf{N}=$ the total number of respondents; size of the sample

\section{Results and Discussion}

\subsection{Results}

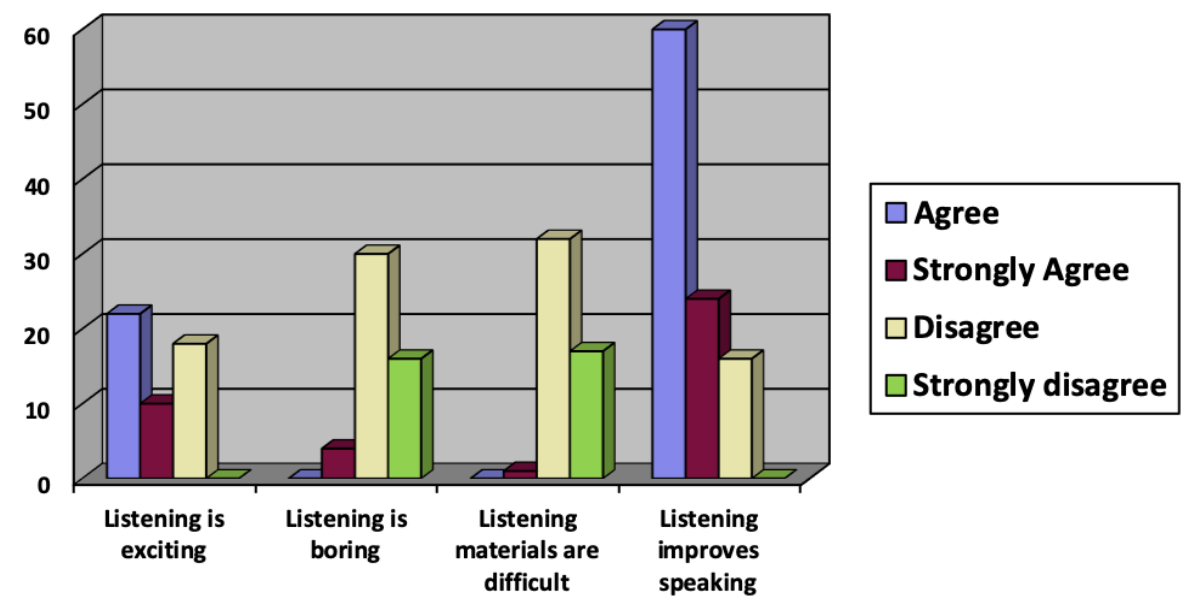

Figure 1. Students' attitude toward listening comprehension

Figure 1 shows that the majority of the learners (64\%) agrees that listening comprehension is an exciting course; only $36 \%$ of them perceive listening as uninteresting. Similarly, only a handful of learners (8\%) agrees that listening is boring, while an overwhelming majority of them (92\%) disagree that their listening instruction is boring. Also, almost all of the learners (98\%) do not perceive the listening comprehension materials they 
are exposed to as difficult to understand; only $2 \%$ think that listening materials are not easy to understand. In addition, an overwhelming majority of the learners (84\%) believe that their speaking skill can benefit from listening exercises.

Table 1: Students' frequency of listening to English news broadcasts

\begin{tabular}{lcc}
\hline Options & Frequency & Percentage \\
\hline Always & 0 & $0 \%$ \\
\hline Often & 10 & $20 \%$ \\
\hline Sometimes & 40 & $80 \%$ \\
\hline Never & 0 & 0 \\
\hline
\end{tabular}

As shown in Table 1, the majority of the learners (80\%) revealed that listening to English news broadcast is not something they do regularly. Only $20 \%$ of them describe that they often expose themselves with English news broadcasts. This finding suggests that English news broadcast is not the type of learning resources they are accustomed with.

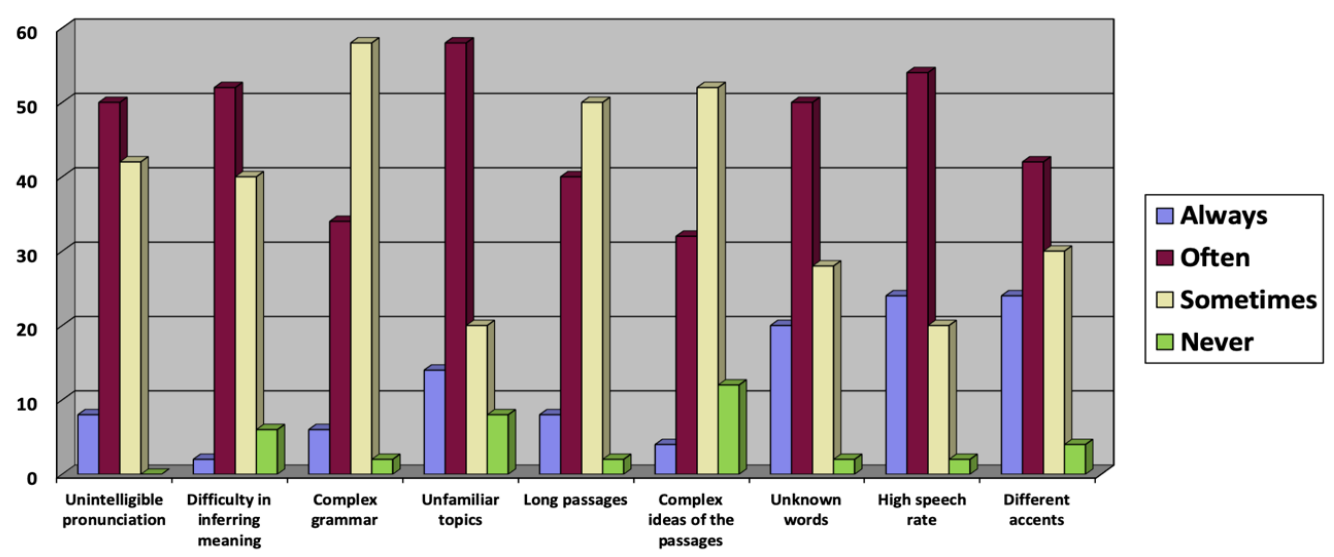

Figure 3. Learners' difficulties in listening to English news broadcasts

The results also pointed out the type of difficulties the learners encounter when listening to English news podcast in their listening comprehension course (see Figure 3). Speakers' high speech rate ( $24 \%$ always and $54 \%$ often) and unfamiliar topics ( $14 \%$ always and $58 \%$ often) top the list, followed in order of frequency by unknown vocabulary ( $20 \%$ always and $50 \%$ often), unfamiliar accents (24\% always and $42 \%$ often), unintelligible pronunciation ( $8 \%$ always and $50 \%$ often), difficulty in inference making ( $2 \%$ always and $52 \%$ often), excessively long passages ( $8 \%$ always and $40 \%$ often), complicated grammatical structure ( $6 \%$ always and $34 \%$ often), and complex ideas of the passage ( $4 \%$ always and $32 \%$ often).

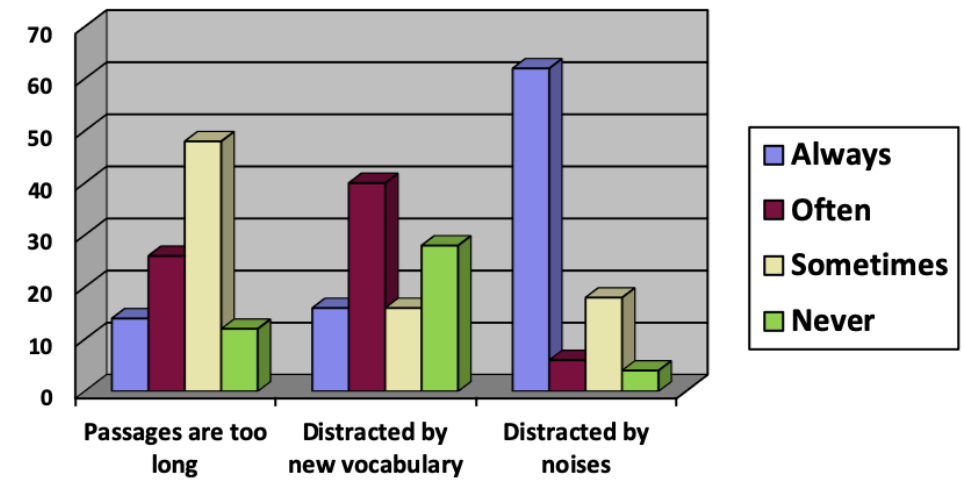

Figure 4. Why learners lose concentration when listening to English news broadcasts 
The learners also indicated three factors affecting their concentration when completing a listening task involving English news broadcasts (See Figure 4). First, many of them (62\% always, $6 \%$ often, $18 \%$ sometimes) have trouble concentrating because of the distractions of the background noises in English news broadcast which interferes with the broadcaster's voice. These distractions include the sounds of heavy machineries operating, other people talking, or airplane passing in the sky. Second, the learners (14\% always, $26 \%$ often, $48 \%$ sometimes) find it difficult to retain focus when listening to long passages. Third, a considerable number of learners ( $16 \%$ always, $40 \%$ often, $16 \%$ sometimes) lose their concentration when they encounter new words which draw their attention and stop them from listening to the next parts of the passage.

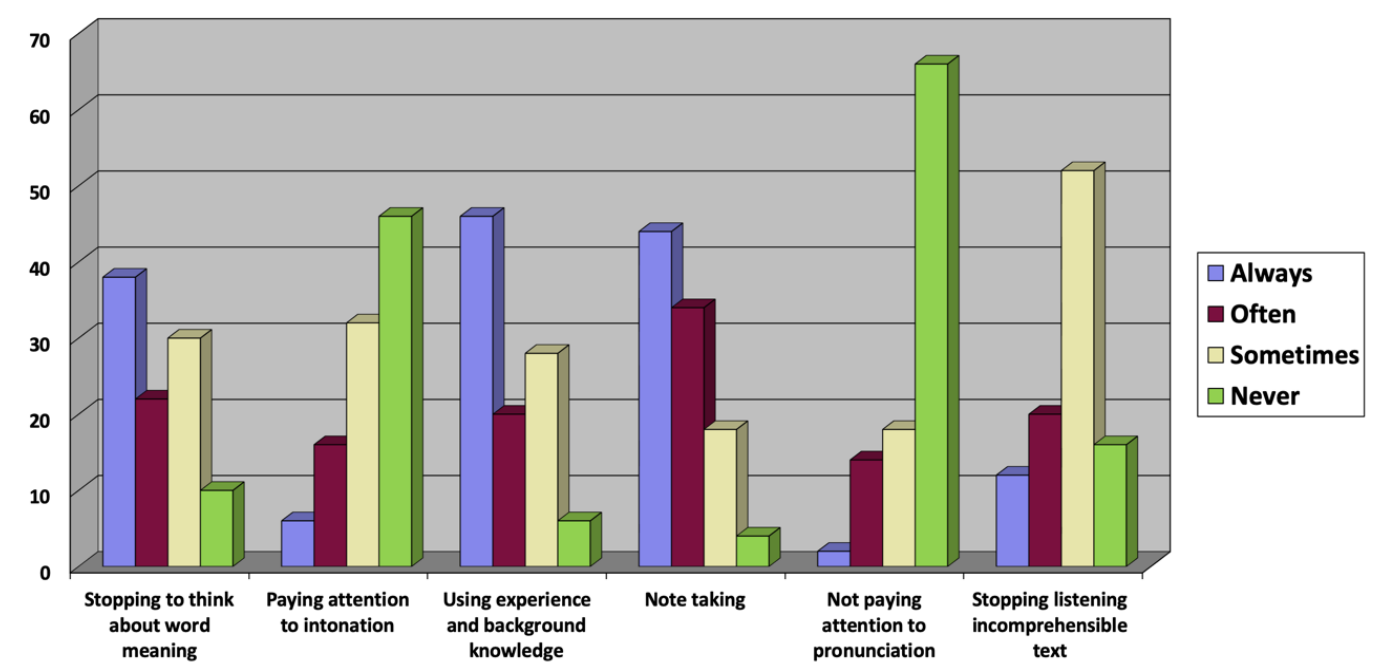

Figure 5. Learners' strategies when listening to English news broadcasts

Figure 5 shows the learners' strategies when dealing with a listening task involving English news broadcasts. They include note-taking (78\%), stopping or pausing to think of meaning of the new of new words (60\%), paying attention to speakers' intonation (22\%). Interestingly, several learners reported that speakers' pronunciation in a news broadcast is not the focus of their attention (16\%), while more than half of the learners stop listening to incomprehensible passage altogether (32\%).

\subsection{Discussion}

In listening to English news broadcast, the learners suggested that their shortage of vocabulary and their difficulty in inferring meaning of unknown words are among the obstacles to comprehending English news broadcast. This finding highlights the relative importance of learners' knowledge of vocabulary in understanding a listening material. Shortage of vocabulary constitutes one of the major reasons for learners' downfall in a listening task (Musa \& Fojkar, 2019; Namaziandost et al., 2019), which can interfere with their comprehension especially when they discontinue listening to know what a word means, as $60 \%$ of the learners in this research admit to doing. This also occurs when learners hear a word they do not fully remember and they allow themselves to get left behind scrambling to figure out what the word means. Unfortunately, by the time they remember, they realize that they have totally missed some essential information or even the sense of what the speaker was saying. It is evident in this study that the majority of the learners listened with the goal of grasping each word and detail, and as a result, they become easily interrupted every time an unfamiliar word or phrase occurs. Learners are 
unable to keep their pace with the speakers in such authentic material as news broadcasts because of their tendency to apply this word-by-word processing in listening, repeatedly bringing their listening to a halt in order to decipher unknown words and ignoring what is coming ahead (Chen, 2013).

Gilakjani and Ahmadi (2011) reiterate that listeners do not have to understand every word in a task. They have to train themselves to ignore less important words and learn to think ahead since, as stipulated by Hamouda (2013), it is both pointless and hardly doable. Teachers can also carefully select a simple news broadcast with familiar words which they know learners can do for the sake of nurturing learners' confidence and stimulating their enthusiasm (Bingol, et al., 2014). Furthermore, if learners are to be exposed with authentic use of language as listening materials, in addition to consistently working on building their vocabulary, it is necessary that they also be drilled regularly in colloquialism and discourse markers in order to develop their skill in inference making (Ebrahimi, 2017). This finding also emphasizes the importance of pre-teaching vocabulary new vocabulary before listening to a news broadcasts or other authentic learning resources since earlier studies have shown learners' better performance and increase in confidence with vocabulary preparation (Emami \& Lashkarian, 2014; Farrokhi \& Modarres, 2012; Gilakjani \& Ahmadi, 2011). Moreover, Liang (2015) emphasized that learners themselves should also make an effort to indulge in authentic communications or interaction which contains a variety of colloquial language so that they are aware native English speakers normally speak with rhythm and intonation woven together by means of words pronounced together in the speech flow.

Nonetheless, knowledge of vocabulary means learners not only recognize a vast number of words and their spelling, but also demonstrate their understanding of the pronunciation of the words. $58 \%$ of the learners in this study claimed that their problems in listening comprehension is partly due to their inability interpret the utterances of native speakers. According to Underwood (1989), learners often miss out on words when listening due to their relative weakness in recognizing a continuous sequence of sounds forming utterances or connected discourse. In this case, they may actually know almost all the words, or have encountered them at some point in their reading or writing activities, but they are just unable to recognize them in the flow of speech. This indicates that their inability to deal with authentic language often characterized by frequent use of connected speech prevents learners' comprehension. It certainly takes time and confidence for EFL learners, even at a higher level, to familiarize themselves with connected speech. However, studies have shown that teacher could provide significant support by simply calling their attention to the continuous sequence of spoken language found in the classroom materials (Kelly, 2006; Kennedy \& Blanchet, 2014; Lee, 2013).

Being unfamiliar with the topics is also reported as a barrier in comprehending a news broadcast by $72 \%$ of the learners. Familiarity with an assigned topic certainly affects comprehension. Learners who are able to activate their background knowledge prior to listening can certainly make more sense of a passage. On the other hand, those who possess little to no access to their background knowledge of a topic will experience difficulty in inferring meaning. Samian and Dastjerdi (2012) state that when exposed to new information, learners should be given an opportunity to use their existing knowledge because it is such a formidable tool to infer meaning of a given passage. Similarly, Mahdavy( 2011) finds that using a topic which learners find familiar increases the chance of acquisition. This is in consistent with previous studies which reported that recognized topics allow learners to use the language much more conveniently (Gilakjani \& Ahmadi, 2011; 
Kazemi \& Zarei, 2015; Walker, 2014). This strongly implies the need for teachers to stimulate learners' prior knowledge especially in a pre-listening phase.

Like any other authentic materials, the use of English news broadcasts in language teaching provides a myriad of advantages. However, some distinguishing characteristics of English news broadcast may stand in learners' way of comprehending a given passage completely. In an EFL classroom, teachers usually speak clearly with standard intelligible English when conveying their ideas to EFL learners. As a result, EFL learners are often found dumbfounded when conversing with a native speaker or listening to such authentic materials as news broadcasts. Most EFL learners are familiar only with resources which are especially-designed for classroom use (Fujita, 2017), whereas in fact, audio or video recordings from ESL or EFL textbooks usually showcase English spoken at a rate that has been modified to be easily understandable by EFL learners. In contrast, English news broadcasts also contain some other features which have been deliberately discarded from the recordings in a conversation textbook, but which one commonly has to deal with in reallife communication. Speakers' speaking at a high rate of speech, or using unfamiliar accents, with noises from vehicles passing by or bystanders chattering in the background are examples of these indispensable features. Hence, rapid speech rate, the use of different accents, and distracting background noises are among common stumbling blocks in listening to an English news broadcast, as reported by consecutively $78 \%, 68 \%$, and $48 \%$ of the learners in this study.

In the case of high speech rate, Underwood (1989) maintained that listening to a narrator speaking at a high speed requires an arduous effort especially when the listeners have no control the speed. This explains why English news broadcasts are not so popular among the teachers since they believe that this type of listening material is still beyond some of their EFL learners' comprehensible input even though they are already at a high level of proficiency. Among EFL learners themselves, there is always a preference for slow-rate materials even if their listening skill is already able to operate at a faster rate. In this case, they should be encouraged and pushed to a higher rate. The finding of this study, thus, suggests that the use of authentic listening materials such as news broadcast should not be at the expense of textbook materials. Learners at a lower level of proficiency tend to show their preference for materials from ESL or EFL coursebook, while those at a higher level of proficiency may benefit greatly from the use of authentic materials. This indicated the need for teacher to accommodate both levels of learners in his or her classroom by alternating the use of both types of resources. When used this way, authentic materials and textbook materials serve well to complete and supplement each other. As stated by Hayati (2010), materials with slow speech rate can function to clear the path to comprehending authentic language for the lower proficiency learners trying to find their way up to a higher level, while authentic materials can be used to assist the more competent learners to acquiring nativelike speech rate.

As is revealed by the finding of this study, the inclusion of a variety of British, American, Australian, Indian or French accents also make English news broadcast so challenging. According to Hamouda (2013), teachers need to familiarize learners with different mainstream native-speaker accents. Teachers need to leave their comfort zone of teaching either British or American English and start introducing other varieties of English such as Canadian English, Australian English, New Zealand English, or even Indian English. Teacher can surely avoid teaching delicate regional accents in deep, but learners should be made aware of the fact that English has an array of dialects and accents that make it such a rich 
language to learn. Teacher can also avoid using news broadcast or other authentic materials with problematic accents altogether unless learners' goal is to get an employment in a transnational company. Otherwise, learners can be spared additional challenge and stick to studying mainstream varieties of English exclusively.

Similarly, noise is also a factor affecting learners' comprehension of a news broadcast. As an external listening barrier, noises interfere with communication and create barriers between the speaker and listener (West \& Turner, 2010). Yang, et al. (2017) reports that manmade noises, industrial noises, as well as noises coming from the crowd occurring in a listening material, can potentially cause distractions to EFL learners. Even for native speakers, listening to authentic materials with noisy background is an uphill task requiring extra effort. For EFL learners, this effort is doubled. This is further reiterated by with Hodoshima et al. (as cited in Fujita, 2017), who found that EFL learners' listening comprehension declines with the presence of background noises. As for pedagogical implication, this finding suggests that teachers should use English news broadcasts in listening instruction only after learners have acquired sufficient level of listening ability to perceive the materials with noisy settings. Also, as far as the learners are concerned, regular exposure to such authentic materials as news broadcasts in addition to coursebook resources is necessary to get accustomed with the noise distractions in the background.

Passage length has also long been cited as a factor affecting EFL listeners' comprehension (Becker, 2016; Ilhan, 2018; Rost, 2011; Tsagari \& Banerjee, 2016; Zhafarghandi et al., 2014), and Hamouda (2012) assert that unnecessarily long listening passages can potentially make learners wearied and eventually lose their focus. Bloomfield et al. (2010) found that long passages overloaded with information may cause learners' working memory to overwork, thus preventing comprehension. Incomprehensible information, subsequently, often draws their attention away, and as a result, they will miss out on the remaining passage. Even when they can refrain themselves from being fixated, they will most probably find difficulties understanding subsequent information which requires comprehending prior materials. Among the methods a teacher can implement in helping listeners to overcome the challenge of a long passage containing a vast amount of information is to let them take notes or replaying it multiple times. In addition, teacher can allow more processing time for EFL learners to internalize the input by implementing frequent and prolonged pauses during a listening task involving authentic materials (Mohamadi, 2013).

\section{Conclusion}

Listening is an ability to recognize and comprehend what a speaker says to acquire some information or messages. In teaching listening comprehension, English news broadcast is among the most easily found authentic materials that can improve both learners' general skills and their confidence in a day-to-day situation. Since they are rich in content, news broadcasts not only augment learners' linguistic and communicative competence, but also broaden their horizon. When properly used in listening classroom, they can effectively engage learners' interest and motivation.

Some difficulties that learners encounter in listening to English news broadcasts are generally brought about by the speakers, the listeners themselves, the content and the physical setting. Problems associated with the speakers include the high speech rate, the use of non-mainstream accents. The barriers related to listeners are shown when listeners stop listening when encountering new words or lose their concentration while listening. 
Difficulties linked with contents are, among others, unfamiliar topics and unknown words scattered across the passage.

Nevertheless, a teacher using English news shows should carefully select familiar and interesting topics that are actually relevant to learners' needs. The teacher should also make available news broadcasts with familiar mainstream accents and vocabulary within learners' level.

\section{ACKNOWLEDGEMENTS}

The completion of this study could not have been possible without the tremendous support and assistance of the Dean of the Department of English Language Teaching, ArRaniry State Islamic University Banda Aceh. The authors also wish to express their sincere gratitude to the head of the Department of English Language Teaching, who provided them an opportunity to conduct the research work in the department.

The authors sincerely thank all the lecturers of the Department of English Language Teaching for their guidance and encouragement in carrying out the study. We also wish to express our gratitude to the officials and other staff members of Ar-Raniry State Islamic University Banda Aceh who rendered their help during the period of the research work.

Last but not the least, the authors thank Dr. Paola Gemme and Dr. Regina St. John from Arkansas Tech University, Russellville, Arkansas, for their insightful comments and enlightening hard questions on this research.

\section{References}

Akmal, S. (2013). A comparative analysis of task-based language teaching (TBLT) criteria in course books for upper intermediate English students. Jurnal IImiah Didaktika, 13(2), 351-372. https://doi.org/10.22373/jid.v13i2.483

Allen, R. Van. (1976). Language Experiences in Communication. Houghton: Houghton Mifflin School.

Becker, A. (2016). L2 Students' Performance on Listening Comprehension Items Targeting Local and Global Information. Journal of English for Academic Purposes, 24, 1-13. https://doi.org/10.1016/j.jeap.2016.07.004

Bingol, M. A., Mart, C. T., Celik, B., \& Yildiz, N. (2014). Listening Comprehension Difficulties Encountered by Students in Second Language Learning Class. Journal of Educational and Instructional Studies in the World, 4(4), 25-30. www.ijonte.org

Bloomfield, A., Wayland, S. C., Rhoades, E., Blodgett, A., Linck, J., \& Ross, S. (2010). What Makes Listening Difficult? Factors Affecting Second Language Listening Comprehension. Journal of English Language Teaching, 9(6), 1-91. https://doi.org/10.21236/ADA550176

Brown, G., \& Yule, G. (2013). Discourse Analysis. Cambridge University Press. https://doi.org/10.1017/CBO9780511805226

Buck, G. (2001). Assessing Listening. Cambridge University Press.

Burns, P. C., \& Broman, B. L. (1975). The Language Arts in Childhood Education. Houghton: Third Edition. Houghton Mifflin Company.

Chen, A. hua. (2013). EFL listeners' Strategy Development and Listening Problems: A ProcessBased Study. Journal of Asia TEFL, 10(3), 81-101.

Creswell, J. W., \& Poth, C. N. (2013). Qualitative Inquiry and Research Design. SAGE Publications, Inc.

Dörnyei, Z., \& Taguchi, T. (2010). Questionnaires in Second Language Research: Construction, 
Administration, and Processing: Second edition. Routledge Taylor \& Francis Group. https://doi.org/10.4324/9780203864739

Ebrahimi, Y. (2017). Discourse Analysis and the Development of English Listening Comprehension for Non-English Fields of Studies in Iran. Journal of Applied Linguistics and Language Research, 4(1), 166-177. http://www.jallr.com/index.php/ JALLR/article/view/505.

Emami, R., \& Lashkarian, A. (2014). The Effect of Pre-Reading Activity on the Listening Comprehension of Intermediate EFL Learners. International Journal of Education and Research, 2(8), 111-122. https://www.ijern.com/journal/2014/August-2014/12.pdf.

Farrokhi, F., \& Modarres, V. (2012). The Effects of two Pre-Task Activities on Improvement of Iranian EFL Learners' Listening Comprehension. Theory and Practice in Language Studies, 2(1), 144-150. https://doi.org/10.4304/tpls.2.1.144-150

Fujita, R. (2017). Effects of Speech Rate and Background Noise on EFL Learners' Listening Comprehension of Different Types Of Materials. Journal of Asia TEFL, 14(4), 638-653. https://doi.org/10.18823/asiatefl.2017.14.4.4.638

Gilakjani, Abbas Pourhosein, \& Sabouri, N. B. (2016). Learners' Listening Comprehension Difficulties in English Language Learning: A literature Review. English Language Teaching, 9(6), 123. https://doi.org/10.5539/elt.v9n6p123

Gilakjani, Abbas Pourhossein, \& Ahmadi, M. R. (2011a). A study of Factors Affecting EFL Learners' English Listening Comprehension and the Strategies for Improvement. Journal of Language Teaching and Research, 2(5). https://doi.org/10.4304/jltr.2.5.977-988

Gilakjani, Abbas Pourhossein, \& Ahmadi, M. R. (2011b). A Study of Factors Affecting EFL Learners' English Listening Comprehension and the Strategies for Improvement. Journal of Language Teaching and Research, 2(5). https://doi.org/10.4304/jltr.2.5.977-988

Hamouda, A. (2012). Listening Comprehension Problems - Voices from the Classroom. $\begin{array}{lll}\text { Language in India, } & \text { 12(8). }\end{array}$ http://www.languageinindia.com/aug2012/v12i8aug2012.pdf.

Hamouda, A. (2013). An Investigation of Listening Comprehension Problems Encountered by Saudi Students in the EFL Listening Classroom. International Journal of Academic Research in Progressive Education and Development, 2(2), 113-155. https://www.semanticscholar.org/paper/An-Investigation-of-Listening-

Comprehension-by-in-Hamouda/b811984d6e30068a62a970b1f75b2e701e0b159e.

Hasan, A. S. (2000). Learners' Perceptions of Listening Comprehension Problems. Language, Culture and Curriculum, 13(2), 137-153. https://doi.org/10.1080/07908310008666595

Hayati, A. (2010). The Effect of Speech Rate on Listening Comprehension of EFL Learners. Creative Education, 01(02), 107-114. https://doi.org/10.4236/ce.2010.12016

Ilhan, B. (2018). Length in Listening Texts as a Single Determiner of Difficulty for Comprehension. Journal of Language and Linguistic Studies, 14(3), 336-346. www.jlls.org

Kazemi, S. A., \& Zarei, L. (2015). The Efficacy of Topic Familiarity on Oral Presentation: Extensive Speaking Assessment Task of Iranian EFL Learners in TBLT. International Journal of Applied Linguistics and English Literature, 4(3), 93-97. https://doi.org/10.7575/aiac.ijalel.v.4n.3p.93

Kelly, G. (2006). How to Teach Pronunciation. New York: Pearson Education. 
Kennedy, S., \& Blanchet, J. (2014). Language Awareness and Perception of Connected Speech in a Second Language. Language Awareness, 23(1-2), 92-106. https://doi.org/10.1080/09658416.2013.863904

Lee, S. (2013). Korean University Students' Listening Comprehension and Learning Effects of Connected Speech Processes in English. Korean Journal of Applied Linguistics, 29(3), 133. https://doi.org/10.17154/kjal.2013.09.29.3.133

Liang, D. (2015). Chinese Learners' Pronunciation Problems and Listening Difficulties in English Connected Speech. Asian Social Science, 11(16), 98-106. https://doi.org/10.5539/ass.v11n16p98

Lingzhu, J., \& Yuanyuan, Z. (2010). The Use of Authentic Materials in Teaching EFL Listening. Humanising Language Teaching Magazine for Teachers and Teacher Trainers, 12(4), 23-29. http://ejournal.unp.ac.id/index.php/isla/article/view/101275.

Liza, K., Adnan, A., \& Ardi, H. (2013). English Department of UNP Students' Ability in Listening to English News. Journal of English Language Teaching, 2(1), 152-159. https://doi.org/10.24036/JELT.V2I1.2601

Mahdavy, B. (2011). The Role of Topic Familiarity and Rhetorical Organization of Texts in L2 Incidental Vocabulary Acquisition. Procedia - Social and Behavioral Sciences, 29, 208217. https://doi.org/10.1016/j.sbspro.2011.11.226

Mohamadi, Z. (2013). Determining the Difficulty Level of Listening Tasks. Theory and Practice in Language Studies, 3(6), 987-994. https://doi.org/10.4304/tpls.3.6.987-994

Morrison, B. (1989). Using News Broadcasts for Authentic Listening Comprehension. ELT Journal, 43(1), 14-18. https://academic.oup.com/eltj/articleabstract/43/1/14/376267?redirectedFrom=PDF.

Musa, N. N., \& Fojkar, M. D. (2019). Correlation Between Students' English Listening Skills, Vocabulary Skills and Out-Of-School Listening Exposure. New Educational Review, 55(1), 42-53. https://doi.org/10.15804/tner.2019.55.1.03

Namaziandost, E., Neisi, L., Mahdavirad, F., \& Nasri, M. (2019). The Relationship between Listening Comprehension Problems and Strategy Usage among Advance EFL Learners. Cogent Psychology, 6(1). https://doi.org/10.1080/23311908.2019.1691338

Palinkas, L. A., Horwitz, S. M., Green, C. A., Wisdom, J. P., Duan, N., \& Hoagwood, K. (2015). Purposeful Sampling for Qualitative Data Collection and Analysis in mixed Method Implementation Research. Administration and Policy in Mental Health and Mental Health Services Research, 42(5), 533-544. https://doi.org/10.1007/s10488-013-0528y

Rao, P. S. (2019). The Effective Use of Authentic Materials in the English Language Classrooms. Shanlax International Journal of Arts, Science and Humanities, 7(1), 1-8. https://doi.org/10.34293/sijash.v7i1.556

Rost, M. (2011). Teaching and Researching Listening. New York: Pearson Education Limited.

Samian, S. H., \& Dastjerdi, H. V. (2012). The Relationship between Prior Knowledge and EFL Learners' Listening Comprehension: Cultural Knowledge in Focus. Mediterranean Journal of Social Sciences, 3(1), 361-370. https://doi.org/10.5901/mjss.2012.03.01.361

Saraswaty, D. R. (2018). Learners' Difficulties \& Strategies in Listening Comprehension. English Community Journal, 2(1), 139. https://doi.org/10.32502/ecj.v2i1.1003

Tsagari, D., \& Banerjee, J. (2016). Handbook of Second Language Assessment. De Gruyter. https://doi.org/10.1515/9781614513827

Underwood, M. (1989). Teaching Listening. New York: Pearson Education Limited. 
Ur, P. (2012). A Course in English Language Teaching (2nd ed.). Cambridge: Cambridge University Press.

Usó-Juan, E., \& Martínez-Flor, A. (2006). Current Trends in the Development and Teaching of the four Language Skills (Vol. 29). Mouton de Gruyter. https://doi.org/10.1515/9783110197778

Walizer, M. H., \& Wienir, P. L. (1978). Research Methods and Analysis: searching for relationships. ew York: Harper and Row.

Walker, N. (2014). Listening: the most Difficult Skill to Teach. Encuentro, 23, 167-175. https://core.ac.uk/download/pdf/58911108.pdf.

West, R., \& Turner, L. (2010). Understanding Interpersonal Communication: Making Choices in Changing Times (2nd ed.). New York: Cengage Learning, Inc.

Widdowson, H. G. (2003). Defining Issues in English Language Teaching. Oxford: Oxford University Press.

Willis, J. (1981). Teaching English Through English: A Course in Classroom Language and Techniques (Handbooks for Language Teachers). London: Longman.

Wong, V., Kwok, P., \& Choi, N. (1995). The Use of Authentic Materials at Tertiary Level. ELT Journal, 49(4), 318-322. https://doi.org/10.1093/elt/49.4.318

Yamane, S., \& Yamane, K. (2012). ABC World News 14. Kinseido. https://www.kansaiu.ac.jp/fl/publication/pdf_department/11/07yamane.pdf.

Yang, X., Jiang, M., \& Zhao, Y. (2017). Effects of Noise on English Listening Comprehension among Chinese College Students with Different Learning Styles. Frontiers in Psychology, 8(10). https://doi.org/10.3389/fpsyg.2017.01764

Yoestara, M., \& Putri, Z. (2019). PODCAST: An Alternative Way to Improve EFL Students' Listening and Speaking Performance. Englisia Journal, 6(1), 15. https://doi.org/10.22373/ej.v6i1.3805

Zhafarghandi, A. M., Barekat, B., \& Homaei, S. (2014). Advances in Language and Literary Studies: A Survey of Iranian EFL Teachers' and Learners' Perceptions toward Authentic Listening Materials at University Level. Advances in Language and Literary Studies, 5(4), 184-197. https://doi.org/10.7575/aiac.alls.v.5n.4p.184 